\title{
PERLINDUNGAN HUKUM KONSUMEN ATAS BARANG YANG TIDAK TERDAFTAR PADA SISTEM BISNIS ONLINE
}

\author{
Sucen* \\ Notaris Maria Hilaria Salim SH
}

\begin{abstract}
One consequence of technological and communication advancement is the business activity that is usually done conventionally has started to shift into the electronic-based system by using a computer network. However, the phenomenon also generates a new problem that is related to the safety standard of products being sold, because many suspected of having no proper approval or license from authorized agency namely the National Agency for Drug and Food Control (NADFC). The cosmetic product is one of the examples.

The objective of this research to analyze and elaborate legal protection through preventive and repressive means to consumers in the online business system from unregistered items or products in NA-DFC. The research used juridical normative approach, a method legal research where the analysis itself does not include data or social factors into account. Performing analysis on legal protection for consumers against unregistered products certainly cannot be separated from the Law of Consumer Protection.

Result of the research shows preventive legal protection does exist and proven by the existence of Law of the Republic of Indonesia No. 8 of 1999 on Consumer Protection which explicitly states its information that consumers have appropriate protection against the act of deceit, harmful or even any action that may lead to dangerous consequences. The repressive legal protection comes in the form of a maximum of five years imprisonment or a maximum fine of Rp. 2.000.000.000,for businesses or producers that produce and/or trade items and/or service that does not fulfill or incompatible with pre-determined standards.
\end{abstract}

Keyword : online business, food and drug monitoring agency, legal protection, consumers

\begin{abstract}
Abstrak
Salah satu dampak dari kemajuan teknologi informasi dan komunikasi adalah kegiatan bisnis yang pada umumnya dilakukan secara konvensional mulai beralih secara elektronik dengan menggunakan jaringan-jaringan komputer (computer network). Namun fenomena tersebut disisi lain juga menimbulkan masalah baru, yaitu terkait dengan standar keamanaman barang yang diperdagangkan karena terindikasi banyak yang tidak memiliki ijin dari lembaga yang berwenang, salah satunya adanya Badan Pengawas Obat dan Makanan (BPOM). Sebagai salah satu contohnya adalah kosmetik.

Tujuan dari penelitian adalah untuk menganalisis dan menguraikan perlindungan hukum secara preventif dan reprseif terhadap konsumen pada sistem bisnis online dari barang-barang yang tidak terdaftar Balai Pengawas Obat dan Makanan
\end{abstract}

*Alamat Korespondensi : Sucen_zhang@yahoo.co.id 
(BPOM). Penelitian ini menggunakan pendekatan yuridis normatif, yaitu penelitian hukum yang dalam melakukan pengkajian hukum dalam bahan hukum bukan data atau faktor sosial. Mengkaji mengenai perlindungan hukum terhadap konsumen dari barang yang tidak berijin BPOM tentu tidak lepas dari UndangUndang Perlindungan Konsumen.

Hasil penelitian ini menyatakan bahwa terdapat adanya perlindungan hukum preventif yaitu diterbitkannya Undang-Undang Nomor 8 Tahun 1999 tentang Perlindungan Konsumen yang secara tegas memberikan informasinya bahwa konsumen mendapatkan perlindungan atas perbuatan yang curang, merugikan bahkan menimbulkan hal-hal yang berbahaya. Perlindungan hukum represif yaitu adanya sanksi berupa pidana penjara paling lama 5(lima) tahun atau pidana denda paling banyak Rp. 2.000.000.000,- (dua milyar rupiah) bagi pelaku usaha yang memproduksi dan/atau memperdagangkan barang dan/atau jasa yang tidak memenuhi atau tidak sesuai dengan standar yang dipersyaratkan.

Kata kunci : Bisnis online, badan pengawas obat dan makanan, perlindungan hukum, konsumen

\section{A. Latar Belakang Masalah}

Aspek kehidupan masyarakat terutama pada bidang perdagangan banyak dipengaruhi oleh kemajuan teknologi informasi dan komunikasi. Kegiatan bisnis yang pada umumnya dilakukan secara konvensional mulai beralih secara elektronik dengan menggunakan jaringan-jaringan komputer (computer network) yaitu internet yang dikenal dengan istilah Electronic-Commerce atau disingkat ECommerce. ${ }^{1}$

Berbeda dengan model bisnis yang dilakukan secara konvensional, ecommerce menciptakan kegiatan bisnis yang lebih efektif karena transaksi bisnis antara pelaku usaha dan konsumen tidak dibatasi oleh ruang dan waktu. ${ }^{2}$ Keterbatasan waktu yang dimiliki konsumen untuk dapat berbelanja secara konvensional, karena banyaknya pekerjaan, kondisi jalan yang sangat ramai hingga terjadi kemacetan menyebabkan timbulnya keinginan konsumen untuk dapat berbelanja kebutuhannya dengan mudah dan cepat. ${ }^{3}$ Keadaan tersebut tentulah merupakan peluang bisnis yang sangat besar bagi para pelaku usaha dengan membuat toko online untuk menawarkan produk-produk barang atau jasa yang akan dijual. Pelaku usaha dalam melakukan bisnis toko online biasanya memanfaatkan aplikasi media sosial seperti: Facebook, Instagram, Twitter, dan Blog. Instagram adalah salah satu aplikasi media sosial yang paling banyak digunakan untuk memasarkan barang. Dengan jumlah pengguna instagram sebanyak 200 juta pada awal tahun 2014, instagram telah menjadi salah satu media sosial untuk menerapkan strategi paling efektif dan efisien dalam bisnis dan

\footnotetext{
${ }^{1}$ Abdul Halim dan Teguh Prasetyo, 2005, Bisnis E-Commerce, Pustaka Pelajar, Yogyakarta, hlm.10.

${ }^{2}$ Abdulah Halim Barkatullah, Urgensi Perlindungan Hak-Hak Konsumen Dalam Transaksi di ECommerce, Jurnal Hukum, Vol. 14, No.2, April 2007, hlm. 250

${ }^{3}$ Ambar Wariati dan Nani Irma Susanti, E-Commerce Dalam Prespektif Perlindungan Konsumen, Jurnal Ekonomi\&Bisni,Vol. 1, No. 2, Nopember 2014, hlm. 2.
} 
pemasaran. Hal ini dikarenakan banyak konsumen yang lebih memilih melakukan pembelian online melalui Instagram. ${ }^{4}$

Alasan dari hal tersebut adalah karena instagram merupakan aplikasi media social yang memiliki kemudahan dalam penggunaannya. Kemudahan dalam menggunakan aplikasi tersebut berpengaruh secara signifikan terhadap sikap yang akan mempengaruhi minat bagi konsumen untuk menggunakan instagram dalam melakukan pembelian secara online. ${ }^{5}$

Menjamurnya sistem jual beli online memunculkan peluang bisnis baru. Jika dilihat dari unsur perjanjian yang ada pada jual beli online, maka perjanjian jual beli online merupakan bentuk perjanjian jual beli biasa. Jual beli dianggap telah berlangsung antara penjual dan pembeli ketika mereka telah menyepakati tentang harga dan barang yang selanjutnya dilakukan penyerahan barang yang dimaksud. ${ }^{6}$

Namun rupanya peluang bisnis dan kemudahan tersebut tidak diimbangi oleh salah satu faktor utama yang menjadi kelemahan konsumen, yaitu tingkat kesadaran konsumen akan haknya masih rendah. Hal ini terutama disebabkan oleh rendahnya pendidikan konsumen. Oleh karena itu, Undang-undang Perlindungan Konsumen dimaksudkan menjadi landasan hukum yang kuat bagi pemerintah dan lembaga perlindungan konsumen swadaya masyarakat unluk melakukan upaya pemberdayaan konsumen melalui pembinaan dan pendidikan konsumen.

Begitu banyak pelaku bisnis yang memanfaatkan konsumen hanya sematamata karena menginginkan keuntungan tanpa memperdulikan hak-hak konsumennya. Sebagai contoh adalah makin maraknya penjualan kosmetik pada sistem bisnis online. Faktanya dalam contoh kasus pertama dilakukan oleh BPOM adalah terjadi di Aceh Tengah yang menyita kosmetik illgal

120 juta Rupiah; Kasus kedua : penarikkan produk kosmetik Lipstick matte merek QL Matte Lipstcik menyebabkan kanker; Kasus ketiga: Penjualan Kosmetik Ilegal Via Online Sentuh dengan Rp17Miliar

Dengan iming-iming wajah yang cantik, cepat dan harga yang terjangkau, konsumen berlomba-lomba untuk membeli tanpa mempedulikan keamanan atas produk yang dipakainya. Penjual berdalih bahwa bukan menjadi kewajibannya untuk menjelaskan dan membuktikan bahwa produk kosmetik tersebut aman digunakan atau tidak selama konsumen tidak menanyakannya.

Jika kita merujuk pada hak konsumen yang seharusnya didapatkan, maka pemerintah Indonesia sudah secara resmi membentuk sebuah badan yang berwenang untuk melakukan pengecekan serta memberikan ijin. Badan yang dimaksud adalah Badan Pengawas Obat dan Makanan (BPOM). Seyogyanya seluruh obat maupun makanan harus melalui proses pengawasan BPOM tersebut,

\footnotetext{
${ }^{4}$ Bayu Indrayana, Kudang Boro Seminar \& Bagus Sartono, Faktor Penentu Minat Penggunaan Instagram Untuk Pembelian Online Menggunakan Techhnology Acceptance Model (TAM) dan Theory Of Planned Behavior (TPB), Jurnal Aplikasi dan Manajemen, Vol. 2, No. 2, Mei 2016, hlm. 139-136.

${ }^{5}$ Ibid

${ }^{6}$ Halimi Purnamasari, Penyelesaian Kasus Pembatalan Sepihak Setelah Pemesanan Yang Dilakukan Pembeli Dalam Perjanjian Jual Beli Melalui Toko Online @naads_shop, Diunduh dari http://etd.repository.ugm.ac.id/
} 
termasuk juga kosmetik didalamnya. Namun yang terjadi di masyarakat adalah banyak ditemukan kosmetik yang tidak mengantongi izin BPOM atau bahkan izin BPOM yang dicantumkan adalah palsu. Bila penjualan dilakukan melalui outletoutlet tentu akan lebih mudah untuk dilakukan razia. Permasalahan justru timbul ketika penjualan kosmetik tersebut dilakukan melalui bisis online. Tentu akan sangat sulit bagi BPOM ntuk melakukan pengawasa serta penindakan.

Berangkat dari keresahan dan kenyataan dilapangan bahwa cukup banyak konsumen yang dirugikan akibat barang yang dibeli dari transaksi jual beli online ini tidak mengantongi ijin dari BPOM.

\section{B. Rumusan Masalah}

1. Bagaimana perlindungan hukum secara preventif terhadap konsumen pada sistem bisnis online dari barang-barang yang tidak terdaftar Balai Pengawas Obat dan Makanan (BPOM)?

2. Bagaimana perlindungan hukum secara represif terhadap konsumen pada sistem bisnis online dari barang-barang yang tidak terdafttar Balai Pengawas Obat dan Makanan (BPOM)?

\section{Metode Penelitian}

Penelitian tidak lain adalah guna melakukan suatu analisa atas permasalahan sebagaimana yang telah dijabarkan pada Bab sebelumnya. Penelitian (research) berarti pencarian kembali. Sebuah penelitian dapat dikatakan sebagai karya tulis ilmiah, maka harus memenuhi unsur metodis, bahwa pencarian dan pembahasan serta penuangan bahan-bahan hukum serta keterangan-keterangan yang telah diperoleh dilakukan dengan menggunakan metode-metode ilmiah. ${ }^{7}$

Untuk menjawab permasalahan dalam penelitian ini, Peneliti akan menggunakan jenis penelitian hukum berupa penelitian hukum yuridis normatif. Penelitian yuridis normatif ini dilakukan dengan cara meneliti bahan pustaka atau data-data sekunder belaka. Penelitian dengan cara meneliti bahan pustaka atau data-data sekunder ini mencakup: ${ }^{8}$

1. Penelitian terhadap asas-asas hukum: bertitik tolak dari bidang-bidang tata hukum (tertulis) tertentu dengan cara mengadakan identifikasi terlebih dahulu terhadap kaidah-kaidah hukum yang telah dirumuskan di dalam perundang-undangan tertentu,

2. Penelitian terhadap sistematik hukum: dilakukan pada perundang-undangan tertentu atau hukum tercatat dengan tujuan untuk mengadakan dentifikasi terhadap pengertian-pengertian pokok/ dasar dalam hukum yaitu masyarakat hukum, subyek hukum, hak dan kewajiban, peristiwa hukum, hubungan hukum dengan obyek hukum,

3. Penelitian terhadap taraf sinkronisasi vertikal dan horizontal: hal yang diteliti adalah sampai sejauh mana hukum positif yang berlaku serasi secara vertikal berdasarkan hirarki perundang-undangan; dan secara horisontal di

\footnotetext{
${ }^{7}$ Amiruddin dsan Zainal Asikin, Pengantar Metode Penelitian Hukum, Jakarta: PT Raja Grafindo Persada, 2012, hal 19

${ }^{8}$ Soerjono Soekanto dan Sri Mamudji, Penelitian Hukum Normatif: Suatu Tinjauan Singkat, (Jakarta:PT Raja Grafindo Persada, 2003), hlm. 13
} 
mana kedudukan hal yang ditinjau harus sederajat dalam tata perundangundangan,

4. Perbandingan hukum: dalam penerapannya, perbandingan bertitik tolak pada paradigma teoritis maupun kerangka konsepsional,

5. Sejarah hukum: dapat tertuju pada perkembangan lembaga-lembaga tertentu seperti perkawinan dan waris; atau sejarah terbentuknya perundangundangan tertentu.

Pada umumnya, penelitian dibedakan antara data yang diperoleh langsung dari masyarakat dan dari bahan-bahan pustaka. Adappun yang dipeoleh langsung dari masyarakat disebut dengan data primer (atau data dasar), sedangkan yang diperoleh dari bahan-bahan pustaka lazimnya dinamakan data sekunder. ${ }^{9}$

Data dalam penulisan ini adalahdata sekunder, yaitu bahan pustaka yang mencakup dokumen-dokumen resmi, buku-buku perpustakaan, peraturan perundang-undangan, karya ilmiah, artikel-artikel, serta dokumen yang berkaitan dengan materi penelitian. Dari bahan hukum sekunder tersebut mencakup tiga bagian, yaitu: ${ }^{10}$

1. Bahan Hukum Primer

Bahan hukum primer, yaitu bahan-bahan hukum yang mengikat. Bahan hukum primer yang digunakan dalam penelitian ini terdiri dari peraturan perundangundangan yaitu Pasal 28D Undang-Undang Dasar 1945 Amandemen Keempat, Kitab Undang-Undang Hukum Perdata, Undang-Undang Nomor 8 Tahun 1999 tentang Perlindungan Konsumen, Undang-Undang Nomor 11 Tahun 2008 tentang Informasi dan Transaksi Elektronik sebagimana diubah dengan UU Nomor 19 Tahun 2016 yang tercatat dalam lembaran Negara RI Tahun 2016 Nomor 251 dan Tambahan Lembaran Negara Nomor 5952

2. Bahan Hukum Sekunder

Bahan hukum sekunder, yang memberikan penjelasan mengenai bahan hukum primer, seperti, rancangan undang-undang, hasil-hasil penelitian, hasil karya dari kalangan hukum, dan seterusnya.

Dalam penyusunan perencanaan penelitiaan (research-design), sebenarnya adalah merupakan suatu dokumen yang mengandung semua kegiatan merencanakan serta melaksanakan penelitian yang berarti suatu tata cara untuk mengumpulkan data dan analisanya. Dengan demikian menemukan suatu pedoman untuk mengumpulkan data, mengolahnya kemudian menganalisa dan di konstruksikan adalah assignment atau format yang tepat dalam pembahasan. Alat pengumpulan data dalam hukum senantiasa bergantung pada ruang lingkup dan tujuan penelitian hukum yang akan dilakukan.

Metode Analisis Data adalah kegiatan yang berupa kajian, telah terhadap hasil pengolahan data dengan dibantu dengan teori-teori yang didapat sebelumnya. Dengan melakukan studi kepustakaan, penulis melakukan research analisis terhadap peraturan perundang-undangan yang berhubungan dengan permasalahan serta menghubungkan secara koheren yang menunjang penelitian ini. Penelitian

${ }^{9}$ Soerjono Soekanto dan Sri Mamudji, 2011, Penelitian Hukum Normatif, Suatu Tinjuan Singkat, Jakarta: PT Raja Grafindo Persada, Hal.12.

${ }^{10}$ Ibid, Hal 13 
ini menggunakan metode kualitatif yang bertolak dari data hukum kemudian menghubungkannya dengan teori-teori hukum yang ada dalam rangka menemukan argumentasi atau konsep baru dalam teori. Analisis pendekatan kualitatif tidak menggunakan angka-angka melainkan berupa gambaran yang menjelaskan suatu keadaan atau deskripsi dengan menggunakan kata-kata atas temuan-temuan.

Oleh karena metode ini lebih mengutamakan mutu atau kualitas dari data dan bukan berupa paparan angka-angka. Analisis data dalam penelitian ini bersifat induktif, yaitu pengembangan konsep yang didasarkan atas data yang ada, mengikuti desain penelitian yang fleksibel sesuai dengan konteksnya.

\section{Hasil Penelitian dan Pembahasan}

Kata perlindungan menurut Kamus Umum Bahasa Indonesia berarti tempat berlindung atau merupakan perbuatan (hal) melindungi, misalnya memberi perlindungan terhadap orang yang lemah. ${ }^{11}$ Menurut Sudikno Mertokusumo, yang dimaksud dengan hukum adalah kumpulan peraturan atau kaedah yang mempunyai isi yang bersifat umum dan normatif, umum karena berlaku bagi setiap orang dan normatif karena menentukan apa yang seyogyanya dilakukan, dan apa yang tidak boleh dilakukan atau harus dilakukan serta menentukan bagaimana caranya melaksanakan kepatuhan pada kaedah-kaedah. ${ }^{12}$

Jadi dapat disimpulkan bahwa perlindungan hukum adalah suatu perbuatan dalam rangka melindungi subjek-subjek hukum dengan norma-norma atau peraturan perundang-undangan yang berlaku (hukum positif) dan pelaksanaannya dapat dipaksakan dengan suatu sanksi.

Menurut Philiphus M. Hadjon, negara Indonesia sebagai negara hukum berdasarkan Pancasila haruslah memberikan perlindungan hukum terhadap warga negara sesuai dengan Pancasila. Oleh karena itu perlindungan hukum berdasarkan Pancasila berarti pengakuan dan perlindungan hukum akan harkat dan martabat manusia atas dasar nilai Ketuhanan Yang Maha Esa, kemanusiaan, persatuan, permusyawaratan, serta keadilan sosial. Nilai-nilai tersebut melahirkan pengakuan dan perlindungan hak asasi manusia dalam wadah negara kesatuan yang menjunjung tinggi semangat kekeluargaan dalam mencapai kesejahteraan Bersama. ${ }^{13}$

Dalam merumuskan prinsi-prinsip perlindungan hukum di Indonesia, landasannya adalah Pancasila sebagai ideologi dan falsafah negara. Konsepsi perlindungan hukum bagi rakyat di Barat bersumber pada konsep-konsep Rechtstaat dan "Rule of The Law". Dengan menggunakn konsepsi barat sebagai kerangka berfikir dengan landasan pada Pancasila, prinsip perlindungan hukum di Indonesia adalah prinsip pengakuan dan perlindungan terhadap harkat dan martabat manusia yang bersumber pada Pancasila. Prinsip perlindungan hukum

11 W.J.S. Poerwadarminta, Kamus Umum Bahasa Indonesia, Cetakan IX, Jakarta: Balai Pustaka, 1986, Hal. 600.

${ }^{12}$ Sudikno Mertokusumo, Mengenal Hukum (Suatu Pengantar), Yogyakarta: Liberty, 1991, Hal.38.

13 Philipus M. Hadjon, Perlindungan Hukum Bagi Rakyat Indonesia, Surabaya: PT. Bina Ilmu, 1987, Hal 84 
terhadap tindak pemerintah bertumpu dan bersumber dari konsep tentang pengakuan dan Perlindungan terhadap hak-hak asasi manusia karena menurut sejarahnya di Barat, lahirnya konsep-konsep tentang pengakuan dan perlindungan terhadap hak-hak asasi menusia diarahkan kepada pembatasanpembatasan dan peletakan kewajiban masyarakat dan pemerintah ${ }^{14}$

Aspek dominan dalam konsep barat tertang hak asasi manusia menekankan eksistensi hak dan kebebasan yang melekat pada kodrat manusia dan statusnya sebagai individu, hak tersebut berada di atas negara dan di atas semua organisasi politik dan bersifat mutlak sehingga tidak dapat diganggu gugat. Karena konsep ini, maka sering kali dilontarkan kritik bahwa konsep Barat tentang hak-hak asasi manusia adalah konsep yang individualistik. Kemudian dengan masuknya hakhak sosial dan hak-hak ekonomi serta hak kultural, terdapat kecenderungan mulai melunturnya sifat individualistik dari konsep Barat. ${ }^{15}$

Dalam menjalankan dan memberikan perlindungan hukum dibutuhkannya suatu tempat atau wadah dalam pelaksanaannya yang sering di sebut dengan sarana perlindungan hukum, sarana perlindungan hukum dibagi menjadi dua macam yang dapat dipahami, sebagai berikut :

\section{Perlindungan Hukum Secara Preventif Terhadap Konsumen Pada Sistem Jual Beli Online Yang Tidak Terdaftar Badan Pengawas Obat dan Makanan (BPOM)}

Perlindungan hukum preventif memberikan kesempatan untuk mengajukan keberatan atau pendapatnya sebelum suatu keputusan pemerintah mendapat bentuk yang definitif. Tujuannya adalah untuk mencegah terjadinya sengketa. Perlindungan ini snagat besar artinya bagi tindakan pemerintah yang didasarkan pada kebebasan bertindak karena dengan adanya perlindungan hukum yang preventif pemerintah terdorong untuk bersifat hati-hati dalam mengambil keputusan yang didasarkan pada diskresi. Di Indonesia belum ada pengaturan khusus mengenai perlindungan hukum preventif.

Dengan adanya suatu Perlindungan hukum secara preventif ini, diharapkan perlindungan ini dapat mendorong agar pemerintah untuk mempertimbangkan setiap pengambilan keputusan, dan masyarakyat dapat secara kritis meberikan mengajukan keberatan atas keputusan itu. ${ }^{16}$

Adapun bentuk perlindungan preventif sebagaimana tertuang didalam Undang- Undang Nomor 8 Tahun 1999 tentang Perlindungan Konsumen, menganut 5 (lima) asas yaitu: ${ }^{17}$

1. Perlindungan konsumen berasaskan manfaat,

Maksud asas ini adalah untuk mengamanatkan bahwa segala upaya dalam penyelenggaraan perlindungan konsumen harus memberikan manfaat sebesar- besarnya bagi kepentingan konsumen dan pelau usaha secara keseluruhan.

14 Philipus M. Hadjon. Op.cit. Hal. 38

15 Sudikno Mertokusumo, Op.cit. Hal 51

${ }^{16}$ Philipus M. Hadjon. Op.cit. Hal 69

${ }^{17}$ Pasal 2 Undang-Undang Nomor 8 Tahun 1999 Tentang Perlindungan Konsumen 
2. Perlindungan konsumen berasaskan keadilan, Asas ini dimaksudkan agar partisipasi seluruh rakyat bisa diwujudkan secara maksimal dan memberikan kesempatan kepada konsumen dan pelaku usaha untuk memperoleh haknyadan melaksanakan kewajibannya secara adil.

3. Perlindungan konsumen berasaskan keseimbangan, Asas ini dimaksudkan untuk memberikan jaminan atas keamanan dan keselamatan kepada konsumen dalam penggunaan, pemakaian, dan pemanfaatan barang/jasa yang dikonsumsi atau digunakan.

4. Perlindungan konsumen berasaskan keamanan dan keselamatan konsumen, Asas keamanan dan keselamatan konsumen dimaksudkan untuk memberikan jaminan atas keamanan dan keselamatan kepada konsumen dalam penggunaan, pemakaian dan pemanfaatan barang da $\mathrm{n} / \mathrm{atau}$ jasa yang dikonsumsi atau digunakan.

5. Perlindungan konsumen berasaskan kepastian hukum.

Asas ini dimaksudkan agar baik pelaku usaha maupun konsumen menaati hukum dan memperoleh keadilan dalam penyelenggaraan perlindungan konsumen, serta negara menjamin kepastian hukum.

Perlindungan Hukum Preventif ini merupakan perlindungan yang memiliki sifat yaitu pencegahan, dimana sebelum seseorang itu dan/atau kelompok melakukan suatu kegiatan atau tindakan yang bersifat negatif atau melakukan suatu kejahatan yang diniatkan di dalamnya sehingga akan dapat menghindarkan atau meniadakan kejadian perbuatan yang konkrit. ${ }^{18}$

Untuk menunjang agar semua fungsi dari BPOM itu bisa berjalan dengan sempurna, maka dalam upaya meningkatkan perlindungan kesehatan masyarakat dari risiko produk obat dan makanan yang tidak memenuhi persyaratan keamanan, khasiat/manfaat, dan mutu, Badan Pengawas Obat dan Makanan (BPOM) berupaya memperkuat Sistem Pengawasan Obat dan Makanan (SisPOM) yang komprehensif dan menyeluruh. ${ }^{19}$

Salah satu konsep dasar SISPOM adalah pengawasan oleh masyarakat/konsumen, melalui peningkatan kesadaran dan peningkatan pengetahuan mengenai kualitas produk yang digunakannya dan cara-cara penggunaan produk yang rasional. Pengawasan oleh masyarakat sendiri sangat penting dilakukan karena pada akhirnya masyarakatlah yang mengambil keputusan untuk membeli dan menggunakan suatu produk.

Pengawasan obat dan makanan memiliki aspek permasalahan berdimensi luas dan kompleks. Oleh karena itu diperlukan sistem pengawasan yang komprehensip, semenjak awal proses suatu produk hingga produk tersebut beredar ditengah masyarakat. ${ }^{20}$

${ }^{18}$ Ibid.

${ }^{19}$ BPOM RI, Badan POM, Ringkasan Eksekutif, diakses dari http://ulpk.pom.go.id/ulpk/?page=profil\&id=9 pada tanggal 15 Agustuus 2019

${ }^{20}$ BPOM RI, Badan POM kerangka konsep SISPOM, diakses dari https://www.pom.go.id/new/view/direct/kksispom pada tanggal 15 Agustuus 2019 
Untuk menekan sekecil mungkin risiko yang bisa terjadi, dilakukan SISPOM tiga lapis yakni :

- Sub-sistem pengawasan Produsen

Sistem pengawasan internal oleh produsen melalui pelaksanaan cara-cara produksi yang baik atau good manufacturing practices agar setiap bentuk penyimpangan dari standar mutu dapat dideteksi sejak awal. Secara hukum produsen bertanggung jawab atas mutu dan keamanan produk yang dihasilkannya. Apabila terjadi penyimpangan dan pelanggaran terhadap standar yang telah ditetapkan maka produsen dikenakan sangsi, baik administratif maupun pro-justisia.

- Sub-sistem pengawasan Konsumen

Sistem pengawasan oleh masyarakat konsumen sendiri melalui peningkatan kesadaran dan peningkatan pengetahuan mengenai kualitas produk yang digunakannya dan cara-cara penggunaan produk yang rasional. Pengawasan oleh masyarakat sendiri sangat penting dilakukan karena pada akhirnya masyarakatlah yang mengambil keputusan untuk membeli dan menggunakan suatu produk. Konsumen dengan kesadaran dan tingkat pengetahuan yang tinggi terhadap mutu dan kegunaan suatu produk, di satu sisi dapat membentengi dirinya sendiri terhadap penggunaan produk-produk yang tidak memenuhi syarat dan tidak dibutuhkan sedang pada sisi lain akan mendorong produsen untuk ekstra hati-hati dalam menjaga kualitasnya.

- Sub-sistem pengawasan Pemerintah/BPOM

Sistem pengawasan oleh pemerintah melalui pengaturan dan standardisasi; penilaian keamanan, khasiat dan mutu produk sebelum diijinkan beredar di Indonesia; inspeksi, pengambilan sampel dan pengujian laboratorium produk yang beredar serta peringatan kepada publik yang didukung penegakan hukum. Untuk meningkatkan kesadaran dan pengetahuan masyarakat konsumen terhadap mutu, khasiat dan keamanan produk maka pemerintah juga melaksanakan kegiatan komunikasi, informasi dan edukasi. Untuk mendorong kemitraan dan kerjasama yang lebih sistematis, dapat dilakukan melalui tahapan identifikasi tingkat kepentingan setiap lembaga/institusi, baik pemerintah maupun sektor swasta dan kelompok masyarakat terhadap tugas pokok dan fungsi BPOM, identifikasi sumber daya yang dimiliki oleh masing-masing institusi tersebut dalam mendukung tugas yang menjadi mandat BPOM, dan menentukan indikator bersama atas keberhasilan program kerjasama. ${ }^{21}$

Dalam menjalankan tugas BBPOM tidak hanya bekerja sendiri, tetapi BBPOM juga bekerjasama dengan Pemerintah daerah/Kota dari masingmasing BPOM itu berada. Contoh di Kantor BPOM di Kabupaten Tangerang melalui kegiatan Aksi Penertiban Kosmetik Ilegal, pada tanggal 14 Agustus 2019 melakukan penertiban kosmetik bersama Dinas Kesehatan Kabupaten Tangerang. Penertiban dilakukan di sarana distribusi kosmetik di sekitar

${ }^{21}$ Yovia dan Resmi, Wewenang dan alur pemeriksaan oleh balai besar pengawasan obat dan makanan bandung terhadap kasus temuan parasite cacing pada produk makerel, Jurnal Famaka, Volume 16 nomor 1, 2018 
kecamatan Pagedangan dan Kelapa Dua, jenis sarana yang diperiksa antara lain importir kosmetik, penotifikasi Dan toko kosmetik, dan ditemukan kosmetik tanpa izin edar. ${ }^{22}$ Dengan adanya program kerjasama tersebut maka diharapkan agar BBPOM dan Pemerintah Daerah/Kota memiliki kepekaan terhadap masalah spesifik di daerah dan memapu bertindak cepat sehingga memberi manfaat yang berarti bagi daerah wilayah kerjanya secara khusu dan seluruh Indonesia pada umumnya.

Obat dan Makanan yang memenuhi standar merupakan tujuan pengawasan yang dilakukan Badan POM. Partisipasi masyarakat menjadi salah satu faktor penting untuk mewujudkan tujuan. Sebagai contoh dalam melalui kegiatan Komunikasi Informasi dan Edukasi (KIE) dengan tema "Pemberdayaan Masyarakat Melalui KIE Pengawasan Obat dan Makanan". Kegiatan KIE yang diselenggarakan pada tanggal 21 September 2018 di kota Tegal didukung oleh anggota Komisi IX DPR RI, Dewi Aryani, selaku salah satu Narasumber pada kegiatan tersebut. Kepala Pusat Data dan Informasi Obat dan Makanan diwakili oleh Ekawati Emilia Hasanuddin mengedukasi masyarakat untuk selalu menerapkan Cek KLIK (Kemasan, Label, Izin Edar dan Kedaluwarsa) dalam memilih produk Obat dan Makanan, masyarakat juga diajak untuk mengenal website Badan POM www.pom.go.id dan aplikasi Cek BPOM.

Kepala Bidang Sertifikasi dan Layanan Informasi Konsumen Balai Besar POM di Semarang, Aryanti, juga mengajak masyarakat untuk melakukan Gerakan Masyarakat Sehat (GERMAS) sebagai upaya preventif dan promotif dalam mewujudkan masyarakat sehat. Penyimpanan dan pemilihan bahan pangan seperti pewarna dan pengawet makanan merupakan contoh gerakan sehat yang dapat dilakukan di rumah tangga.

Narasumber menghimbau masyarakat menjadi konsumen yang cerdas dimulai dari Cek KLIK untuk memilih Obat dan Makanan dan tidak percaya begitu saja kepada setiap informasi Obat dan Makanan yang beredar di media Sosial maupun media massa.

Untuk mendorong kemitraan dan kerjasama yang lebih sistematis, dapat dilakukan melalui tahapan identifikasi tingkat kepentingan setiap lembaga/institusi, baik pemerintah maupun sektor swasta dan kelompok masyarakat terhadap tugas pokok dan fungsi BPOM, identifikasi sumber daya yang dimiliki oleh masing-masing institusi tersebut dalam mendukung tugas yang menjadi mandat BPOM, dan menentukan indikator bersama atas keberhasilan program kerjasama. Komunikasi yang efektif dengan mitra kerja di daerah merupakan hal yang wajib dilakukan, baik oleh Pusat maupun BPOM sebagai tindak lanjut hasil pengawasan. ${ }^{23}$

22 BPOM RI, Badan Pom Beraksi Menertibkan Peredaran Kosmetik Ilegal, Kantor BPOM di Kabupaten Tangerang Amankan Kosmetik Senilai Ratusan Juta Rupiah, diakses dari https://www.pom.go.id/mobile/index.php/view/berita/16619/Beraksi-Menertibkan-PeredaranKosmetik-Ilegal--Kantor-BPOM-di-Kabupaten-Tangerang-Amankan-Kosmetik-Senilai-RatusanJuta-Rupiah.html pada tanggal 14 Agustus 2019 pukul 23:51wib

${ }^{23}$ BPOM RI, Badan POM Selalu Cek KLIK Untuk Obat dan Makanan yang Aman, diakses ldari https://www.pom.go.id/new/view/more/berita/14862/Selalu-Cek-KLIK-Untuk-Obat-danMakanan-yang-Aman.html pada tanggal 22 September 2018 pukul 22:43 WIB 
Dengan cara kegiatan seperti contoh diatas maka dalam hal tersebut dapat ditujukan melindungi masyarakat dari peredararan obat dan makanan yang tidak memenuhi syarat mutu dan keamaan beserta BBPOM tidak hanya memeriksa sampel yang diajukan saja, tapi jga mengadakan sampling dan pengujuan produk beredar.

\section{Perlindungan Hukum Secara Reprensif pada Sistem Jual Beli Online Yang Tidak Terdaftar Badan Pengawas Obat dan Makanan (BPOM).}

Perlindungan Hukum yang Represif bertujuan untuk menyelesaikan sengketa. Penanganan perlindungan hukum oleh Pengadilan Umum dan Peradilan Administrasi diIndonesia termasuk kategori perlindungan hukum ini. Prinsip perlindungan hukum terhadap tindakan pemerintah bertumpu dan bersumber dari konsep tentang pengakuan dan perlindungan terhadap hak-hak asasi manusia karena menurut sejarah dari barat, lahirnya konsep-konsep tentang pengakuan dan perlindungan terhadap hak-hak asasi manusia diarahkan kepada pembatasan-pembatasan dan peletakan kewajiban masyarakat dan pemerintah.

Prinsip kedua yang mendasari perlindungan hukum terhadap tindak pemerintahan adalah prinsip negara hukum. Dikaitkan dengan pengakuan dan perlindungan terhadap hak-hak asasi manusia, pengakuan dan perlindungan terhadap hak-hak asasi manusia mendapat tempat utama dan dapat dikaitkan dengan tujuan dari negara hukum.

Dalam rangka melindungi konsumen yang dirugikan akibat penggunaan kosmetik yang mengandung bahan berbahaya, maka produk kosmetik yang terbukti tidak memenuhi syarat perlu mendapatkan tindakan secara yuridis dengan mendasarkan pada ketentuan peraturan perundang-undangan yang berlaku. Pasal 62 Undang-Undang No.8 Tahun 1999 tentang Perlindungan Konsumen ditegaskan sanksi berupa pidana penjara paling lama 5(lima) tahn atau pidana denda paling banyak Rp. 2.000.000.000,- (dua milyar rupiah) bagi pelaku usaha yang memproduksi dan/atau memperdagangkan barang dan/atau jasa yang tidak memenuhi atau tidak sesuai dengan standar yang dipersyaratkan dan ketentuan peraturan perundangan-undangan, tidak mencantumkan tanggal kadaluarsa atau jangka waktu penggunaan/pemanfaatan yang paling baik atas barang tersebut, tidak memasang label atau membuat penjelasan barang yang memuat nama barang, ukuran, berat/isi bersih atau netto, komposisi, aturan pakai, tanggal pembuatan, akibat sampingan, nama dan alamat pelaku usaha serta keterangan lain untuk penggunaan yang menurut ketentuan harus dipasang/dibuat (Pasal 8 ayat 1 huruf a, g dan i Undang-Undang No. 8 Tahun 1999 tentang Perlindungan Konsumen). Sedangkan terhadap pelanggaran yang mengakibatkan luka berat,sakit berat, cacat tetap, atau kematian diberlakukan ketentuan pidana yang berlaku (Pasal 62 ayat 3 Undang-Undang No.8 Tahun 1999 tentang Perlindungan Konsumen).

Upaya pemberantasan terhadap peredaran kosmetk yang tidak memenuhi ketentuan, dilakukan kegiatan penyelidikan yang meliputi operasi gabungan daerah, operasi gabungan nasional, penelusuran dan pengembangan tindak 
lanjut deteksi dini, inspeksi dadakan, penelusuran kasus serta penyelidikan dan penyidikan tindak pidana kosmetik dalam rangka pro justicia dan sanksi administratif.

Perlindungan hukum represif oleh Dinas Kesehatan dilakukan melalui penyitaan produk kosmetik,pemusnahan produk kosmetik dan pro justicia terhadap pelaku yang terbukti menjual produk kosmetik berbahaya.Bagi konsumen yang dirugikan akibat pemakaian kosmetik dapat melakukan penyelesaian sengketa di luar pengadilan sebagaimana yang tercantum dalam pasal 15 Undang-Undang No. 8 Tahun 1999 tentang Perlindungan Konsumen. Perlindungan Konsumen yang pada dasarnya memberi dua pilihan untuk penyelesaian sengketa yaitu penyelesaian melalui pengadilan dan penyelesaian di luar pengadilan.

Adapun penyelesaian di luar pengadilan yakni melalui Badan Penyelesaian Sengketa Konsumen. Penyelesaian Sengketa Konsumen di Badan Penyelesaian Sengketa Konsumen dilakukan berdasarkan prinsip cepat, murah, dan sederhana. Badan Penyelesaian Sengketa Konsumen menangani kasus yang umumnya bersifat perdata, yang umumnya bersifat ganti rugi langsung yang dialami konsumen akibat kesalahan/kelalaian pelaku usaha. Penyelesaian sengketa di Badan Penyelesaian Sengketa Konsumen dilakukan dengan cara konsiliasi, mediasi, dan arbitrase.

Selain dilakukan tindakan pencegahan dan pengawasan, BPOM juga melakukan tindakan penindakan terhadap pelanggaran yang dilakukan oleh produsen maupun hasil dari riset BPOM yang mengakibatkan ditariknya suatau produk maupun bahan baku dari produk tersebut. Permasalahan justru timbul setelah transaksi selesai dilakukan, dimana konsumen mulai memanfaatkan barang dan/atau jasa yang dibelinya tersebut, namun kemudian merasakan efek sampingnya. Kepuasan konsumen atau kekecewaannya berkenaan dengan transaksi yang diselenggarakan dapat menjadi kenyataan. Kepuasaan konsumen akan menyebabkan konsumen untuk selanjutnya setia dan tidak beralih dari merek barang atau jasa tertentu, sehingga pelaku usaha bersangkutan akan dapat mempertahankan langganannya.

Pada prinsipnya perlindungan hukum represif dapat diberikan tidak hanya melalui tindakan pro justicia melainkan juga dengan metode penyelesaian sengketa di luar pengadilan melalui Badan Penyelesaian Sengket Konsumen, dengan mengedepankan perlindungan terhadap hak-hak konsumen dan juga menciptakan sistem perlindungan konsumen yang mengandung unsur kepastian hukum sehingga menumbuhkan kesadaran bagi pelaku usaha untuk berbuat jujur serta bertanggung jawab dalam memproduksi barang atau jasa.

Permasalahan justru timbul setelah transaksi selesai dilakukan, dimana konsumen mulai memanfaatkan barang dan/atau jasa yang dibelinya tersebut, namun kemudian merasakan efek sampingnya. Kepuasan konsumen atau kekecewaannya berkenaan dengan transaksi yang diselenggarakan dapat menjadi kenyataan. Kepuasaan konsumen akan menyebabkan konsumen untuk selanjutnya setia dan tidak beralih dari merek barang atau jasa tertentu, sehingga pelaku usaha bersangkutan akan dapat mempertahankan langganannya. 
Sebaliknya, keadaan menjadi berbeda apabila konsumen merasa tidak puas terhadap kegunaan dan/atau pemakaian dari suatu barang atau penyelenggaraan jasa yang diperoleh dari pelaku usaha. Dalam hal ini konsumen merasakan kerugian dari penggunaan barang dan/atau jasa bersangkutan. Disinilah permasalahan berujung pada keinginan konsumen untuk meminta pertanggungjawaban pihak penjual. Permasalahan inilah yang biasanya berujung pada sebuah sengketa.

Berkaitan dengan hal itu, UUPK memberikan pengaturan atas tindakan yang harus dilakukan oleh pelaku usaha dalam antara lain:

\section{Pasal 7}

huruf f: Pelaku usaha wajib memberi kompensasi, ganti rugi dan/atau penggantian atas kerugian akibat penggunaan, pemakaian dan pemanfaatan barang dan/atau jasa yang diperdagangkan.

huruf g: Pelaku usaha wajib memberi kompensasi, ganti rugi dan/atau penggantian apabila barang dan/atau jasa yang diterima atau dimanfaatkan tidak sesuai dengan perjanjian.

2. Pasal 19 ayat (1)

Pelaku usaha bertanggung jawab memberikan ganti rugi atas kerusakan pencemaran dan/atau kerugian konsumen akibat mengkonsumsi barang dan/atau jasa yang dihasilkan atau diperdagangkan.

3. Pasal 25 ayat (1)

Pelaku usaha yang memproduksi barang yang pemanfaatannya berkelanjutan dalam batas waktu sekurang-kurangnya 1 (satu) tahun wajib menyediakan suku cadang dan/atau fasilitas purna jual dan wajib memenuhi jaminan atau garansi sesuai dengan yang diperjanjikan.

4. Pasal 26

Pelaku usaha yang memperdagangkan jasa wajib memenuhi jaminan dan/atau garansi yang disepakati dan/atau diperjanjikan.

Tahap-tahap diatas tidaklah secara tegas terpisah satu sama lain. Mungkin saja tahap pertama dan kedua langsung terjadi dalam satu kegiatan transaksi konsumen. Misalnya konsumen datang ke suatu toko melihat barangnya, mencari dan mendapat sekedar informasi mengenai barang tersebut. Ketika konsumen merasa sudah cukup "mengenal" produk tersebut, maka ia langsung membelinya

Pelaku usaha telah melakukan beberapa pelanggaran yang dirumuskan dalam UUPK dikarenakan kegiatan pemasaran yang telah dilakukan yang dapat digolongkan sebagai praktek niaga negative. Oleh karena itu, terhadap kerugian yang telah diderita oleh konsumen, pelaku usaha bertanggung jawab untuk memberikan penggantian kerugian sebagaimana yang diatur dalam Pasal 19 ayat (1) UUPK.

Selanjutnya dalam ayat (2) dinyatakan bahwa ganti kerugian yang diberikan oleh pelaku usaha dapat berupa: berupa pengembalian uang atau penggantian barang dan/atau jasa yang sejenis atau setara nilainya, atau perawatan kesehatan dan/atau pemberian santunan yang sesuai dengan ketentuan 
perundang- undangan yang berlaku. Hal ini juga dikaitkan kepada konsumen yang menderita kerugian harus memperjuangkan hak-haknya untuk mendapatkan advokasi, perlindungan dan upaya penyelesaian sengketa perlindungan konsumen secara patut (Pasal 4 huruf e) dan untuk mendapatkan kompensasi, ganti rugi dan/atau penggantian apabila barang dan/atau jasa yang diterima tidak sesuai dengan perjanjian atau tidak sebagaimana mestinya (Pasal 4 huruf h).

Menurut Pasal 19 ayat (3) UUPK, pemberian ganti rugi tersebut harus dilakukan paling lambat 7 (tujuh) hari setelah tanggal transaksi. Apabila pelaku usaha sampai dengan jangka waktu tersebut di atas, tidak memberikan ganti kerugian yang diminta oleh konsumen, sebagaimana yang dirumuskan dalam Pasal 23 UUPK maka konsumen bersangkutan dapat mengajukan gugatan kepada BPSK ataupun kepada Badan Peradilan Umum di tempat kedudukan konsumen. Konsumen telah melakukan tindakan yang sesuai dengan pasal tersebut, dengan mengajukan pengaduan secara tertulis untuk penyelesaian sengketa ke BPSK karena sebelumnya upaya konsumen untuk melakukan pembicaraan guna mendapatkan solusi dari kerugian yang dideritanya tidak ditanggapi oleh pelaku usaha.

Apabila Badan POM mendapat laporan mengenai peredaran kosmetik berbahaya, maka bagian penyelidikan Badan POM langsung mengkoordinasikan untuk melakukan pengecekan. Pada saat pengecekan kosmetik yang diduga mengandung bahan berbahaya tersebut tidak langsung disita atau dihancurkan, tetapi dibeli satu atau dua buah produk kosmetik dengan uang negara dan diuji di laboratorium. Dan apabila benar adanya peredaran kosmetik yang mengandung bahan berbahaya pada suatu toko kosmetik maka Badan POM akan melakukan sesuai dengan SOP (Standrt Operational Procedur), ${ }^{24}$ kosmetik tersebut akan disita dan apabila telah mendapatkan persetujuan dari Pengadilan kemudian penyidik melakukan pemusnahan untuk kemudian dibakar di tempat pembuangan akhir. Pengawasan yang dilakukan Badan POM hanya sebatas pengamanan produk dan penyitaan terhadap produk atau barangnya.

Pelaku usaha juga dapat dibebankan tanggung jawab atas sanksi pidana berkenaan dengan pelanggaran dalam melakukan praktek niaga, khususnya terkait dengan ketentuan yang terdapat dalam UUPK. Pasal 19 ayat (4) UUPK mengatur bahwa tanggung jawab pelaku usaha untuk pemberian ganti kerugian tersebut tidak menghilangkan tanggung jawab pidana berdasarkan pembuktian terhadap unsur kesalahan. Pasal 45 ayat (3) UUPK juga merumuskan bahwa penyelesaian sengketa di luar Pengadilan tidak menghilangkan tanggung jawab pidana, maka walaupun telah tercapai kesepakatan antara kedua belah pihak yang bersengketa yang dikuatkan dengan surat perjanjian perdamaian, tetapi tidak menghilangkan tanggung jawab pidana dari pihak pelaku usaha.

Apabila dikaitkan dengan Pasal 62 UUPK mengenai ketentuan pidana, maka pelaku usaha dapat dikenakan tuntutan sanksi pidana sebagai berikut:

${ }^{24}$ BADAN POM RI, Laporan tahunan layanan informasi publik, PPID Badan Pom Tahun 2017 
Sanksi pidana dalam Pasal 62 ayat (1) Terkait dengan Pelanggaran Pasal 8 ayat (1) huruf a, g, dan j:, maka berdasarkan dalam Pasal 62 ayat (1) UUPK dapat dikenakan pidana penjara paling lama 5 (lima) tahun atau pidana denda paling banyak Rp. 2.000.000.000 (dua milyar rupiah).

Sehingga apabila pelaku usaha terbukti telah melakukan pelanggaran berupa memperdagangkan barang yang tidak memenuhi atau tidak sesuai standart, tidak mencantumkan tanggal kadaluwarsa, dan tidak mencantumkan informasi/atau petunjuk dalam bahasa Indonesia, maka pelaku usaha tersebut haruslah bertanggung jawab secara pidana.

Selain sanksi pidana di atas, pelaku usaha juga dapat dikenakan hukuman tambahan sebagaimana diatur dalam Pasal 63 UUPK, berupa:

a. Perampasan barang tertentu;

b. Pengumuman keputusan hakim;

c. Pembayaran ganti rugi;

d. Perintah penghentian kegiatan tertentu yang menyebabkan timbulnya kerugian konsumen;

e. Kewajiban penarikan barang dari peredaran, atau

f. Pencabutan izin usaha.

Menurut UUPK, sejak semula, para pihak yang berselisih, khususnya dari pihak konsumen, dimungkinkan untuk menyelesaikan sengketa itu mengikuti beberapa lingkungan peradilan, misalnya peradilan umum atau konsumen memilih jalan penyelesaian diluar pengadilan. ${ }^{25}$

1. Penyelesaian Sengketa Konsumen Melalui Pengadilan

Pasal 45 UUPK mengatakan bahwa konsumen yang merasa dirugikan dapat menggugat pelaku usaha melalui lembaga yang bertugas menyelesaikan sengketa antara konsumen dan pelaku usaha atau melalui peradilan yang berada di lingkungan peradilan umum.

Yang berhak melakukan gugatan terhadap pelanggaran yang dilakukan pelaku usaha diatur dalam pasal 46 ayat 1 UUPK, yaitu:

a. Seorang konsumen yang dirugikan atau ahli waris yang bersangkutan;

b. Sekelompok konsumen yang mempunyai kepentingan yang sama;

c. Lembaga perlindungan konsumen swadaya masyarakat yang memenuhi syarat, yaitu yang berbentuk badan hukum atau yayasan, yang dalam anggaran dasarnya menyebutkan dengan tegas bahwa tujuan didirikannya organisasi tersebut adalah untuk kepentingan perlindungan konsumen dan telah melaksanakan kegiatan sesuai dengan anggaran dasarnya;

d. Pemerintah dan/atau instansi terkait apabila barang dan/atau jasa yang dikonsumi atau dimanfaatkan mengakibat kerugian materi yang besar dan/atau korban yang tidak sedikit.

Maksud dari Pasal 46 ayat (1) yaitu:

a. Bahwa seorang konsumen yang dirugikan atau ahli waris yang bersangkutan sebagaimana maksud dari huruf a pasal 46 ayat (1) UUPK, penyelesaian sengketa konsumen dapat dilakukan melalui

${ }^{25}$ Ahmadi Miru, Op.Cit. hlm 88 
lembaga yang bertugas menyelesaikan sengketa konsumen yaitu melalui badan penyelesaian sengketa (BPSK) sebagaimana yang ditentukan dalam UUPK atau melalui peradilan di lingkungan peradilan umum.

b. Sedangkan gugatan yang di ajukan oleh kelompok atau class action, lembaga perlindungan konsumen swadaya masyarakat atau pemerintah sebagaimana yang dimaksud huruf $b$, huruf $c$, dan $d$ pasal 46 ayat (1) UUPK, penyelesaian sengketa diajukan melalui peradilan umum. Penyelesaian melalui pengadilan mengacu pada ketentuan tentang peradilan umum yang berlaku, serta harus di ajukan oleh yang benar-benar dirugikan dan dapat di buktikan secara hukum salah satu di antaranya adalah adanya bukti transaksi.

2. Penyelesaian Sengketa Konsumen Diluar Pengadilan

Lembaga yang bertugas menyelesaikan sengketa antara konsumen dan pelaku usaha diluar pengadilan menurut UUPK adalah BPSK. Penyelesaian sengketa konsumen di luar pengadilan diselenggarakan untuk mencapai kesepakatan mengenai bentuk dan besarnya ganti rugi atau mengenai tindakan tertentu untuk menjamin tidak akan terjadi kembali atau tidak akan terulang kembali kerugian yang diderita oleh konsumen.

Pasal 52 huruf a UUPK mengatakan bahwa tugas dan wewenang BPSK adalah melaksanakan penanganan dan penyelesaian sengketa konsumen, dengan cara melalui mediasi atau arbitrase atau konsiliasi. Mediasi adalah suatu proses penyelesaian sengketa antara dua pihak atau lebih melalui perundingan atau cara mufakat dengan bantuan pihak netral yang tidak memiliki kewenangan memutus. Mediasi sebagai salah satu alternative penyelesaian sengketa di luar pengadilan, ditempuh atas inisiatif salah satu pihak atau para pihak, di mana majelis BPSK bersifat aktif sebagai pemerantara dan/atau penasehat, pihak ketiga yang bersifat netral terhadap sengketa. Arbitrase menurut Keputusan Menteri Perindustrian Dan Perdagangan Republik Indonesia Nomor:350/Mpp/Kep/12/2001 Tentang Pelaksanaan Tugas Dan Wewenang Badan Penyelesaian Sengketa Konsumen Menteri Perindustrian Dan Perdagangan Republik Indonesia adalah proses penyelesaian sengketa konsumen di luar pengadilan yang dalam hal ini para pihak yang bersengketa menyerahkan sepenuhnya penyelesaian sengketa kepada BPSK. Sedangkan konsiliasi adalah proses penyelesaian sengketa konsumen di luar pengadilan dengan perantaraan BPSK untuk mempertemukan para pihak yang bersengketa, dan penyelesaiannya diserahkan kepada para pihak.

Dalam penyelesaian sengketa konsumen dengan melihat cara pada pasal 52 UUPK diselesaikan terlebih dahulu, pertemuan langsung antara konsumen dan pelaku usaha atau melalui bantuan pihak ketiga. Dengan konsultasi atau negosiasi terjadi proses tawar-menawar untuk mencapai kesepakatan terhadap penyelesaian sengketa konsumen yang terjadi antara pelaku usaha dan konsumen. Dengan cara mediasi, atau konsiliasi 
ada pihak ketiga yang ikut membantu pihak yang bersengketa menemukan jalan penyelesaian di antara mereka. Pihak ketiga yang dimaksud di sini adalah pihak yang netral, tidak memihak kepada salah satu pihak yang bersengketa. Pada penyelesaian seperti ini kerugian yang dapat dituntut sesuai dengan pasal 19 ayat 1 UUPK terdiri dari kerugian karena kerusakan, pencemaran, dan kerugian lain akibat dari mengonsumsi barang dan/atau jasa.

Bentuk penggantian kerugian dapat berupa:

1. pengembalian uang seharga pembelian barang dan/atau jasa;

2. penggantian barang dan/ atau jasa sejenis atau setara nilainya;

3. perawatan kesehatan; atau

4. pemberian santunan yang sesuai.

Jika cara-cara diatas tidak dapat menghasilkan keputusan yang diinginkan kedua belah pihak yang bersengketa atau tidak ada kata sepakat maka undang-undang menyediakan penyelesaian sengketa di dalam pengadilan.

Berdasarkan penjelasan yang telah diuraikan pada bab ini, dapat ditarik kesimpulan bahwa untuk melindungi konsumen akibat kerugian yang dilakukan pelaku usaha, konsumen dapat melakukan upaya hukum dengan cara menyelesaikan sengketa yang terjadi melalui jalur pengadilan atau melalui jalur diluar pengadilan. Penyelesaian sengketa melalui jalur pengadilan dilakukan melalui peradilan umum. Sedangkan penyelesaian sengketa diluar pengadilan dapat dilakukan oleh para pihak melalui lembaga BPSK. Penyelesaian sengketa di luar pengadilan dilaksanakan untuk mencapai kesepakatan mengenai bentuk dan besarnya ganti rugi atau mengenai tindakan tertentu untuk menjamin tidak akan terulang kembali kerugian yang diderita oleh konsumen.

Sejalan dengan permasalahan pada tesis ini maka penyelesaian sengketa diluar pengadilan terkait dengan produk kosmetik yang tidak memiliki izin edar tidak pernah dijumpai. Hal ini dikarenakan semua kegiatan yang berkaitan dengan produk kosmetik tanpa izin edar tidaklah dapat diselesaikan dengan cara non penal. Selain itu akibat yang ditimbulkan dari peredaran produk kosmetik yang tidak memiliki izin edar sangat berat oleh karena nya penyelesaian hanya ditemui melalui jalur pengadilan.

\section{E. Kesimpulan}

1. Pelindungan Preventif dapat terlihat dari adanya upaya yang dilakukan pemerintah untuk membuat segenap peraturan perundang-undangan, sebagai contoh adalah diterbitkannya Undang-Undang Nomor 8 Tahun 1999 tentang Perlindungan Konsumen yang secara tegas memberikan informasinya bahwa baik konsumen maupun pelaku usaha (baik penjual maupun produsen) untuk tetap memegang teguh prinsip bahwa konsumen mendapatkan perlindungan dari negara dan oleh karenanya berbagai macam perbuatan yang curang, merugikan bahkan menimbulkan hal-hal yang berbahaya bagi konsumen akan mendapatkan sanksi yang tegas. 
2. Perlindungan Represif dalam rangka dalam rangka melindungi konsumen yang dirugikan akibat penggunaan kosmetik yang mengandung bahan berbahaya, maka produk kosmetik yang terbukti tidak memenuhi syarat perlu mendapatkan tindakan secara yuridis dengan mendasarkan pada ketentuan peraturan perundang-undangan yang berlaku. Pasal 62 UndangUndang No.8 Tahun 1999 tentang Perlindungan Konsumen ditegaskan sanksi berupa pidana penjara paling lama 5(lima) tahun atau pidana denda paling banyak Rp. 2.000.000.000,- (dua milyar rupiah) bagi pelaku usaha yang memproduksi dan/atau memperdagangkan barang dan/atau jasa yang tidak memenuhi atau tidak sesuai dengan standar yang dipersyaratkan dan ketentuan peraturan perundangan-undangan, tidak mencantumkan tanggal kadaluarsa atau jangka waktu penggunaan/pemanfaatan yang paling baik atas barang tersebut, tidak memasang label atau membuat penjelasan barang yang memuat nama barang, ukuran, berat/isi bersih atau netto, komposisi, aturan pakai, tanggal pembuatan, akibat sampingan, nama dan alamat pelaku usaha serta keterangan lain untuk penggunaan yang menurut ketentuan harus dipasang/dibuat.

\section{DAFTAR PUSTAKA}

\section{Buku}

Abdul Halim dan Teguh Prasetyo, 2005, Bisnis E-Commerce, Pustaka Pelajar, Yogyakarta.

Amiruddin dsan Zainal Asikin, Pengantar Metode Penelitian Hukum, Jakarta: PT Raja Grafindo Persada, 2012

Beni Ahmad Soebani, Metode Penelitian Hukum, Cet. Ke-1, Pustaka Setia, Bandung, 2009

Philipus M. Hadjon, Perlindungan Hukum Bagi Rakyat Indonesia, Surabaya: PT. Bina Ilmu, 1987

Soerjono Soekanto dan Sri Mamudji, Penelitian Hukum Normatif: Suatu Tinjauan Singkat, (Jakarta:PT Raja Grafindo Persada, 2003

Sudikno Mertokusumo, Mengenal Hukum (Suatu Pengantar), Yogyakarta: Liberty, 1991

Sugiyono, Metode Penelitian Kuantitatif, Kualitatif, dan R \& D, Alfabeta, Bandung, 2012 
W.J.S. Poerwadarminta, Kamus Umum Bahasa Indonesia, Cetakan IX, Jakarta: Balai Pustaka, 1986

\section{Artikel Jurnal}

Abdulah Halim Barkatullah, Urgensi Perlindungan Hak-Hak Konsumen Dalam Transaksi di ECommerce, Jurnal Hukum, Vol. 14, No.2, April 2007

Ambar Wariati dan Nani Irma Susanti, E-Commerce Dalam Prespektif Perlindungan Konsumen, Jurnal Ekonomi\&Bisnis,Vol. 1, No. 2, Nopember 2014

Theory Of Planned Behavior (TPB), Jurnal Aplikasi dan Manajemen, Vol. 2, No. 2, Mei 2016

Yovia dan Resmi, Wewenang dan alur pemeriksaan oleh balai besar pengawasan obat dan makanan bandung terhadap kasus temuan parasite cacing pada produk makerel, Jurnal Famaka, Volume 16 nomor 1, 2018

\section{Internet}

Halimi Purnamasari, Penyelesaian Kasus Pembatalan Sepihak Setelah Pemesanan Yang Dilakukan Pembeli Dalam Perjanjian Jual Beli Melalui Toko Online @naads_shop, Diunduh dari http://etd.repository.ugm.ac.id/

BPOM RI, Badan POM, Ringkasan Eksekutif, diakses dari http://ulpk.pom.go.id/ulpk/?page=profil\&id=9

BPOM RI, Badan Pom Beraksi Menertibkan Peredaran Kosmetik Ilegal, Kantor BPOM di Kabupaten Tangerang Amankan Kosmetik Senilai Ratusan Juta Rupiah,diaksesdari https://www.pom.go.id/mobile/index.php/view/berita/16619/BeraksiMenertibkan-Peredaran-Kosmetik-Iegal--Kantor-BPOM-di-KabupatenTangerang-Amankan-Kosmetik-Senilai-Ratusan-Juta-Rupiah.html

BPOM RI , Badan POM Selalu Cek KLIK Untuk Obat dan Makanan yang Aman,ldiakseslari https://www.pom.go.id/new/view/more/berita/14862/Selalu-Cek-KLIKUntuk-Obat-dan-Makanan-yang-Aman.html

\section{Peraturan Perundang-undangan}

Undang-Undang Nomor 8 Tahun 1998 tentang Perlindungan Konsumen Undang-Undang Nomor 19 Tahun 2016 tentang perubahan atas Undang-Undang Nomor 11 Tahun 2008 Tentang Informasi dan Transaksi Elektronik sebagimana diubah dengan UU Nomor 19 Tahun 2016 yang tercatat dalam lembaran Negara RI Tahun 2016 Nomor 251 dan Tambahan Lembaran Negara Nomor 5952

Peraturan Pemerintah Nomor 82 Tahun 2012 tentang Penyelenggaraan Sistem dan Transaksi Elektronik

Peraturan Pemerintah Nomor 82 Tahun 2012 tentang Penyelenggaraan Sistem dan Transaksi Elektronik. Tambahan Lembaran Negara Republik Indonesia Nomor 5348 
